LET: Linguistics, Literature and English Teaching Journal

||Volume |9||Issue||2||Pages||49-71||2019\|

|P-ISSN: 20869606; E-ISSN: 25492454|

Available online at: http://jurnal.uin-antasari.ac.id/index.php

\title{
EXPLORING VOLITION IN PUBLIC SPEAKING CLASS AMONG THE ENGLISH EDUCATION STUDENTS IN SANATA DHARMA UNIVERSITY
}

\author{
Aplonia Nelci Ke Lomi \\ aploniakl@gmail.com \\ Sanata Dharma University, Yogyakarta, Indonesia \\ Concilianus Laos Mbato \\ cons@usd.ac.id \\ Sanata Dharma University, Yogyakarta, Indonesia
}

\section{Article History: \\ Received: $13^{\text {th }}$ August 2019 \\ Accepted: $14^{\text {th }}$ December 2019 \\ Corresponding Author:}

Tel.:

cons@usd.ac.id

Keywords:

Volition; Motivation

Protection Strategies;

Public Speaking skill;

Anxiety-provoking

activity
Public speaking is frequently referred to as an anxiety-provoking activity. Volition is linked to individuals' willpower and persistence to face distraction in achieving particular goals. The aim of this study is exploring the volitional strategies used by English speaking class students and the factors that particularly influenced the students in dealing with the anxiety in public speaking. The participants are the 30 public speaking class students. This study used a questionnaire and interview as the instruments for data collection. The volitional strategies found in this study are split into two kinds: action control and emotion control strategies. The factors influencing students in learning public speaking revealed are inferiority or lack of selfesteem, audience pressures, the absence of preparation, references, vocabulary; and unpredictable examination. The researcher concluded that the students show high volitional stage with their own strategies to overcome anxiety and distractions in public speaking class. This research is undertaken to encourage EFL students to overcome their anxiety and fear in speaking English.

\section{INTRODUCTION}

Public Speaking as one of the language skills plays an important role in communication. According to Sari (2012), public speaking is a process of communication which imparts messages from a speaker to a group of audiences 
and the audiences are supposed to create an interpretation of the messages, which are composed of the information (p.1). However, Dincer (2017) explicitly stated that among the four main language skills (listening, speaking, writing, and reading), speaking is often accepted as the most difficult one to acquire. When individuals speak in the target language, they often experience a high level of anxiety and thus become more unwilling to take part in conversational activities. The existence of motivation is good but there also has to be a commitment to the realization of the motivation. Generally, most individuals choose to be motivated, but only a few can destroy the obstacles and commit themselves to attain their goals.

Volition belongs to the pure and absolute commitment that an individual has to achieve particular goals. Haggard and Lau (2013) stated that volition alludes to the capacity of people to take actions based on their goals, beliefs, and inspiration, instead of external stimulation and causes. In relation to speaking, Macintyre (2016) proposed that speech requires the coordination of a number of driving and restricting forces that are able to operate with or without specific speaker awareness. Considering the importance of volition especially in foreign language learning and the importance of the speaking skill as a neglected language skill in EFL teaching, this study has sought to explore the existence of volition in the participants and how far they are committed to speaking English despite all issues of language anxiety that probably also happen to them. Considering the current status of English as a foreign language in Indonesia, not so many people use it in their daily communication. When the people start to use the language, apparently their anxieties appear because they are afraid of making mistakes. The case is also happens to the participants who are majoring English Education and expected to be English teachers in the future. The spesific conntext of this study is Sanata Dharma University. The university embraces Ignatian pedagogy, concentrating on academic excellence and humanist principles (Mbato, 2013). Ignatian Pedagogy had a significant impact on the theoretical and methodological direction of this study because it emphasizes the growth of each student as a whole (p.4). The students are expected to be a professional teachers 
who are embedded excellency and humanist principle with fewer problems of public speaking and anxiety. The problem statements of the research are: (1) How do the students of Public Speaking class display volition in learning public speaking skill? (2) What are the volitional strategies used by the students of English Public Speaking Class in learning the public speaking skill? (3) What are the factors that influence the students of English public speaking class in learning public speaking skill? In summary, the purpose of this study is to portray the set volitional strategies of a group of undergraduate students in a public speaking class and the reasons why the students should adopt volitional strategies.

\section{The Concept of Volition}

Historically, there had been two levels of motivation. The first is "will", which relates to the desires or purposes of a person, along with a faith that it is within one's authority to fulfill the desire or achieve the goal and the second level is the act of using the "will" or volition, referring to a practice of transforming desires into actions (James, 1890; Paul R. Pintrich \& Schunk, 2002; in Keller, J. M., Deimann, M., \& Liu, Z. 2005). According to Elstad (2012), the etymological origin of volition is from Latin: "vol-" (derived from "velle", to want) with suffix "ition". Corno (Corno, 1993, 1994) described volition as part of a bigger framework of self-regulation involving motivation and other processes of cognition. Kuhl (1987) suggested his concept of action control to define the difference between pre-decision and post-decision processing. Volition for learning concerns procedures engaged in preserving and implementing a learning intention until it is achieved (Corno 1993; Kuhl 1985). Volition in learning is the willingness to undertake, continue and achieve a specific learning objective, whether officially or institutionally defined or self-selected or conceived.

Zimmerman (1994) suggested the importance of volitional strategies in the development of self-regulation. He argued that it is not enough simply to want to be self-regulated in learning. Students must strive to self-regulate their academic performance and have the capacity to keep their goals from distracting or rivals (Zimmerman, cited in Mbato, 2013, p.37). He proposed a model of SelfRegulatory Process in his theory. This model suggests that self-regulated learners 
have engaged in the process of self-regulation through three cyclical stages: a phase of forethought, a phase of volitional or performance control, and a phase of self-reflection. Forethought precedes action, volitional control includes procedures during efforts and self-reflection includes the awareness of factors that influence the responses to these experience (Mbato, 2013). In particular, volition is a part of self-regulation which maintains the desire for learning until the goals of learning are met, particularly when carrying out self-regulation when confronted with distractions such as exhaustion, boredom and tiresome or uninteresting activities (Onoda, 2014).

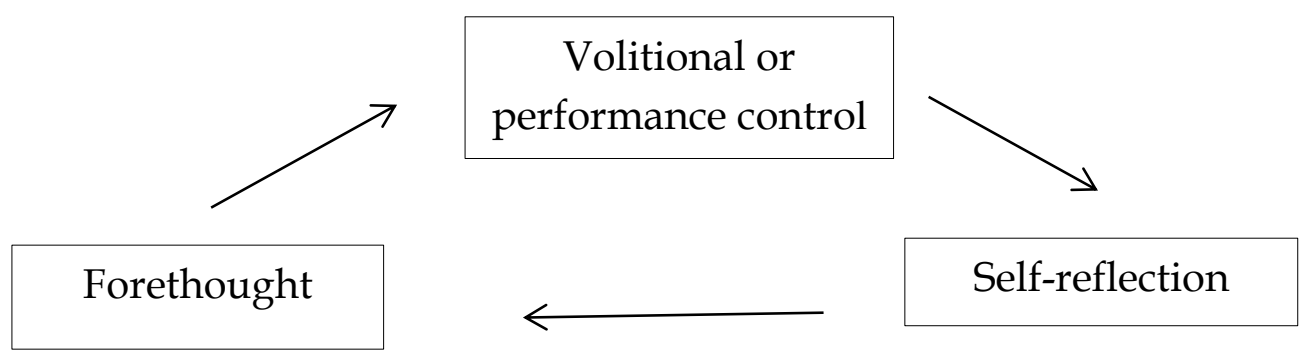

Figure 1. Zimmerman's (2000) Model of Self-Regulatory Process

There are two terms of volition argued by the scientists in this latest decade. The first term is conscious volition. According to Haggard et al., (2013), studies about neural correlates of conscious volition are being actively investigated. They stated that the most important legacy from the scientists in the past is the argument that volition may simply involve a set of conscious experiences with visual awareness or emotional states of individuals. In other words, volition consists of the experiences that happen consciously, with the combination of visual awareness and emotional states. The second key development is the identification of a specific brain mechanism in animals and humans that could form the basis of volition (p. 285).

On the other hand, Gligorov (2017) presents his statement that elements of the interactive ability of individuals could be accomplished without consciousness. He claims that there could be unconscious volitional actions that actually showed as ways of displaying purposeful behavior. In his study, he presented an 
experiment conducted by Libet, Wright, and Gleason (1982) in which they asked their participants to flick their wrist whenever they felt the urge to do so. Using electroencephalography (EEG), they showed that the movement of the participants' wrist was followed by preparatory activity in the brain. They called the experiment as a burst of electrical activity in the scalp readiness potential. In a further study, Libet and colleagues (1983) demonstrated that the conscious intention to perform an action, what they called the first awareness of the wish to act, was also preceded by unconscious activity in the brain (p. 151). Gligorov (2017) also presented evidence that unconscious volitional action indicates that purposeful behavior could not be considered as a reliable indicator of consciousness (p. 152).

"My argument is only that the evidence for unconscious volitional action demonstrates that purposeful behavior is not a reliable indicator of consciousness." (Gligorov, 2017, p. 152).

Volition and self-determination are quite similar. However, according to Ryan and Deci $(1991,2000)$ who proposed Self-determination theory (SDT), the keyword for SDT in education is the autonomy; autonomy in managing the learning process. In theory, individuals have their own autonomy to create and manage their efforts to achieve their purposed goals promoted by their intrinsic motivational spirit (p.342). In other words, the focus of self-determination theory is the freedom within the autonomy of the individuals to learn based on what they want. The concept of volition which is proposed by Corno, L., \& Kanfer, R. (1993) is focused to they way individuals set up their own resources that help to allocate time and mental energy to certain tasks (p.303). It includes implementing the resources when necessarily directing and controlling efforts towards goals. Individuals who have a sense of self-determination are using their autonomy to explore ways and resources while the ones who possess volition are more keeping in pushing themselves to be on the right track, whatever will be in the process. SDT learners are free to explore because they have their autonomy while volitional learners are not only free but also in control by their inner self toward their goal attainment because they have a commitment (Ryan, R. M., \& Deci, E. L. 
2000; Corno, L., \& Kanfer, R. 1993). Eventually, by the existence of volition that supports their autonomy, individuals will be encouraged actively to reach their goals.

“....Such deep, holistic processing (Kuhl \& Fuhrmann, 1998) is facilitated by a sense of choice, volition, and freedom from excessive external pressure toward behaving or thinking a certain way. In this sense, support or autonomy allows individuals to actively transform values into their own" (Ryan, R. M., \& Deci, E. L., 2000, p.74).

\section{Public Speaking And Its Anxiety}

Speaking as one of the basic language skills plays a significant part in the daily life communication. However, Jones (2017) claims that speaking in a foreign language in front of an audience can be an intimidating idea. Besides the lexical, syntactic and semantic issues, future potential speakers need to resolve anxiety and other emotional issues (Jones, 2017, p.48). Macintyre (2016) explicitly mentions the existence of language anxiety in language learners that captures the worry and negative emotional reaction aroused when learning or using a second or foreign language. Despite the intrinsic difficulties, we believe that it is an honorable task to teach our ESL / EFL students to speak in public with confidence (Jones, 2017). However, as language teachers mostly are concentrated on how they push the students' motivation and encourage them to communicate, they should also realize that a strong level of anxiety will probably restrain the students' actions.

In general, volition engages foreign language acquisition students to take actions and be confident in delivering public speaking. The existence of volition offers a way of specifying how motivational tendencies are implemented in the decisions the students make, such as deciding to speak up or stay silent and confining themselves to their anxiety (Macintyre, 2016). There are many results of studies which showed that students who have the high degree on volitional strategies and integrative motivation are working harder and learning faster with their ability to protect their motivation than those who are low on integrative motivation (Yee, Abidin, 2014, p. 130). 
Good public speaking skills can empower our students to communicate their thoughts and views better and to be successful in the job market and other fields of life (Jones, 2017). Nikitina (2011) also stated that improving the students' ability to speak to others and learning to talk about who they are and what they are doing with natural confidence and authenticity can go a long way in increasing the students' social circle, building powerful relationships with successful, like-minded individuals and creating new friends (p.16).

\section{METHOD}

This study explores volition and presents the findings and discussion about the volitional strategies and factors that influence the students' learning in public speaking class, Sanata Dharma University. This research used a mixed qualitativequantitative methodology. Since it is not just collecting various quantitative and qualitative data (e.g. questionnaire and interviews) but also collecting, analyzing and integrating both quantitative and qualitative results. Creswell (2014) has indicated that the importance of the different approaches to study-trends and personal experiences-can contribute better than one type of data collection can alone to the understanding of the research issues (p.3). In this research, the researcher analyzed and integrated the results of the types of data instruments to answer the research questions provided before. Tenses for research reports

\section{Participants}

This research was conducted in the English Language Education Study Program (ELESP) at Sanata Dharma University. The criteria of the participants in this research were the following: the students who had chosen the Public Speaking course and have access to the course material and they had agreed to participate in this research voluntarily. As a result, 30 students of the public speaking class were selected and participated in this study. It was conducted in the middle of semester, during September and October 2018. The 30 students participated in the online questionnaire and 10 students participated in the interviews or sharing sessions.

\section{Data Collection}

Aplonia Nelci Ke Lomi 
The researcher asked for permission to the Public Speaking lecturers in order to conduct research in their class, and the researcher asked for students' willingness to join this study by providing a consent form to the students. The study is done through an online questionnaire and interviews. The interviews are categorized in semi-structural interviews. After analyzing the result of the questionnaire, the researcher picked 10 students whose volition strategies are adopted well and poorly. They were interviewed in order to get more qualitative data. For reason of triangulation, the researcher also conducted sharing sessions with the lecturers of the public speaking class after the interviews and questionnaire were conducted for different insights into the topic of research. Tenses.

\section{Research Instruments}

An online questionnaire was given to students in an attempt to get data about their learning motivation and state of volition. In this case, the writer employed questionnaire consisted of 20 items. The researcher adopted the form of the questionnaire from Mbato (2013) in his study that aimed to investigate whether a metacognitive approach to teaching reading in an EFL context could facilitate self-regulation of learners. It was surveyed through eight statements aimed at determining whether the learners were persistent in achieving their objectives despite negative pressures such as those of their peers or surroundings. In this study, the participants were asked to fill the online questionnaire provided by the researcher to get the general data about their general perception about their motivation in class, the efforts that they gain during the class and their goals in acquiring public speaking skill in the class. After the online questionnaire, the researcher conducted semi-structured interviews to get more details. The researcher conducted the interviews with three major points: prior learning experiences of the students, current situation, and environment, and their learning goals and goals for the future.

Aplonia Nelci Ke Lomi 


\section{FINDINGS AND DISCUSSIONS}

This study explores the existence of volition in the Public Speaking class, particularly for achieving the students' learning goals in a public speaking class. The findings are categorized into three parts: the result of an online questionnaire regarding the students' self-perception of volition, the volitional strategies adopted by the students in facing tasks of public speaking class.

The following is the result of an online questionnaire conducted by the researcher to find out the students were persistent in achieving their objectives despite negative pressures from the audiences in public speaking or the surroundings.

Table 1 Students Responses Regarding Volition

\begin{tabular}{llccc}
\hline No. Statements & Agree & Undecided & Disagree \\
\hline 1. & $\begin{array}{l}\text { Once I have made my goals in } \\
\text { life, I try to achieve them }\end{array}$ & $3 \%$ & $6 \%$ \\
\hline 2. I monitor my speaking $80 \%$ & $17 \%$ & $3 \%$ \\
& performance in order to achieve \\
my learning goals especially in & & \\
acquiring English Public \\
Speaking skill
\end{tabular}

3. When doing public speaking, I $67 \% \quad 20 \% \quad 13 \%$ feel my confidence and I think I am going to make it

4. I am the type of person that is $64 \% \quad 20 \% \quad 16 \%$ persistent in achieving my learning goals especially in acquiring English Public Speaking skill 


\begin{tabular}{|c|c|c|c|c|}
\hline 5. & $\begin{array}{l}\text { I am the type of person that is } \\
\text { able to protect my learning goals } \\
\text { from distractions and troubles }\end{array}$ & $54 \%$ & $33 \%$ & $13 \%$ \\
\hline 6. & $\begin{array}{l}\text { I can handle negative peer } \\
\text { pressure in relation to my learning } \\
\text { goals especially when doing a } \\
\text { public speaking }\end{array}$ & $64 \%$ & $17 \%$ & $19 \%$ \\
\hline 7. & $\begin{array}{l}\text { My surroundings will not prevent } \\
\text { me from achieving my learning } \\
\text { goals especially in acquiring } \\
\text { English Public Speaking skill }\end{array}$ & $60 \%$ & $23 \%$ & $17 \%$ \\
\hline 8. & $\begin{array}{l}\text { Overall, I am the type of person } \\
\text { that will keep trying until I } \\
\text { achieve my learning goals } \\
\text { especially in acquiring English } \\
\text { Public Speaking skill }\end{array}$ & $84 \%$ & $10 \%$ & $6 \%$ \\
\hline
\end{tabular}

The students filled the questionnaire with the options that represented their state of volition in learning and acquiring the public speaking skill. From the table above, we could see that the students showed a positive result regarding volition. $91 \%$ of them stated that once they had a goal, they will try to achieve, meanwhile only $6 \%$ of the students who did not positively have the willpower to achieve their goals. The students were encouraged to recognize that making learning goals was an important step in language learning, but it was equally or even more important to protect them from distraction and to be determined to achieve them (Mbato, 2013). $80 \%$ of the students stated that they monitor their learning process, especially in public speaking class which involves their speaking performances whereas $3 \%$ of the students did not monitor their improvement. 


\section{Volitional Strategies Applied By The Public Speaking Students}

During the interview, the participants reflected their past performances in dealing with public speaking: The students mostly stated that after doing the evaluation, they discovered their lacks in public speaking and they learned from their mistakes. The students mentioned particular strategies for facing public speech or presentation. Therefore, the researcher categorized the strategies into two kinds of volitional strategies:

\section{Action Control Strategies}

Based on the Kuhl theory (1987), there are strategies for action control that can be used as quickly as an active process reaches the current condition (through action). Commitment to achieving a specific objective is the basic requirement for implementing the action control strategy. In this study, the action control strategies adopted by the public speaking students are:

\section{Making Notes}

Making notes help students avoid missing significant points. In public speaking, it enables speakers as the bait to remember all the stuff they are going to speak when they read the notes again. One of the students said he usually felt "lost" while speaking in front of many people. He tended to memorize the speech material, but sometimes because of the nervous feeling, he did not know what to say. Therefore, before the performance, he made notes about the major points linked to the presentation. He did that while waiting for his turn and thought it could make him more well-prepared and comfortable waiting for his turn.

"I usually made notes about the points of the presentation in the classroom while waiting for my turn'”- Student 11

Looking for references (Reading texts, articles, TED videos)

Student 07 expressed that she was still lacking in terms of reference and vocabulary. She, therefore, maintained her motivation and read many texts in English, article or watch TED talk to add her reference on how to speak well in public, generally before the presentation or public speaking. This student also 
reflected on how she is committed to improving her speaking skills and strategies. Although she has many weaknesses, she has continued to improve herself by looking for many references and it suggests her increasing understanding of the significance of volition in meeting her learning objective.

"Considering my strategies; how do I cope with it, I decided to broaden my understanding, point of view and vocabulary. I read Indonesian / English reading texts so there's no absence of vocabulary, so what I'm going to say later... And I also discovered styles of references to talk... Sources I used are news articles and sometimes videos like TED talk"-Student 07

\section{Memorizing the Outlines and Big Points}

Student 11 stated that memorizing the outline of the speech and the significant points in the speech were the methods that he used. He expressed that during the presentation he was easy to be lost at times. Therefore, he needed to make an outline and the large points to be developed.

"Before the presentation, I memorized the outline with the significant points.

So I only had to develop the outline and the points in the presentation"-

Student 11

Help-seeking

Some students attempted to seek support from their friends. They learned they need their classmates to ask for guidance and support. One of the students said she sometimes lacked insights in a public speaking class. Therefore, she generally looks for ideas to develop her speaking style to make her feel comfortable while speaking. She maintained her motivation to find her own style regarding speaking.

"I've got to dig my brain. I understand I could discover it. I'm still looking for ideas. But it's still stuck. My friends assisted me to come up with opinions. But I've got to search again. How do I talk in my own style?"Student 08

Aplonia Nelci Ke Lomi 


\section{Emotion Control Strategies}

These are the strategies that are connected with the emotions of the students. Generally, the strategies were used by the students to control anger or anxiety while facing public speaking:

Being talk active

Some students had a high level of anxiety or nervous feeling before facing a presentation or speaking before many people. For instance, student 18 said she usually felt nervous before every presentation and began to have a stomachache. She also said she couldn't stand quietly waiting for her turn. Her strategy to overcome the situation is that she would be more talkative than usual. Because she feels it might neutralize her anxiety and nerves. She would speak to her colleagues in looking for a better feeling during the interaction with them.

"Usually the most disturbing feeling I've ever personally experienced is anxiety. Because of that intense feeling, I would have a stomachache. I'm also going to be more talkative; for instance, ask a friend to talk about anything to neutralize my nervous feeling"- Student 18

\section{Holding Items}

One of the students said it was her habits that there should be something she holds when she speaks in front of people. It was used to control her hands ' movements and unconsciously made her feel more comfortable performing public speaking or presentation.

"I've ever experienced when I forgot to take something to hold. As a consequence, because my hand could not be controlled, I unconsciously move the tables in front of me. I sidelined it until it was tidy. If my hand did not bring anything, the impact would come to items in front of me. I believed I had already broken the table" -Student 18

"I could stand still, but it was not possible for my hands. I was panicking. I've been confused. I would realize it until my friends look at me and ask what you're doing there? with their weird gazes on me. What came to her?

Aplonia Nelci Ke Lomi

LET: Linguistics, Literature and Language Teaching Journal Vol. 9 No. 22019 
I've got to hold on to something in a presentation. A pencil, for example. Having a microphone is good. I can play the cable" - Student 18

Hands and body movements

Whether consciously or not, there are movements performed by students when they speak in front of the class. These movements were carried by the students indirectly to control themselves from being too anxious in front of their friends.

"Sometimes I did movements because I wanted to feel comfortable, but I did not realize it often. My voice may sound calm, but my hands were in action."

- Student 18

"But the effect is that there are at least a few moments in the presentation when I played my hands or made hair straight, or when there were popes like Uhmm ...'”- Student 18.

Avoiding direct eyes contact with the audiences

Some of the students said that one of the ways of avoiding nervous when delivering a public speech is that they will never look directly into the audience's eyes. The students claim that if they look straight into the audience's eyes, their concentration would be interrupted and their focus on the content would be lost. They may be carried away by the audience gaze. Another strategy is that students keep in mind that the audiences in front of them are only inanimate objects and will not influence them.

"Well, it's because I began to understand my fear. I always attempt to see my friends, but not straight in their eyes"- Student 18

"Yes, that's okay. I assume there's no one there, they're all dead objects, I usually don't see the faces of the audience"- Student 10

Aplonia Nelci Ke Lomi

LET: Linguistics, Literature and Language Teaching Journal Vol. 9 No. 22019 
Factors That Influenced Students' Public Speaking

In this research, the researcher discovered several factors influencing students in learning and mastering the public speaking skill. These factors are described below:

Inferiority and Lack of Self-Esteem

Some students said she did not like to speak to people. They are struggling in the class because they are overwhelming with inferiority. They said they had many inadequacies in English, particularly in obtaining the ability to speak in front of many people. Some of them are even conscious of this problem.

"I understand I have low self-esteem, minimal vocabulary, bad grammar, and pronunciation. That's what makes me wonder "am I capable of doing this?" - Student 08

"I'm the type of student who does not like to speak to many people. If there are a small number of people; for instance, in a group discussion, it's fine for me. I understand I lack self-confidence" - Student 19

Pressures from the audience

It could be seen that the factor of the audience also affects the students in the delivery of the public speech. Student 11 said he had encountered anxiety when talking in public because he was not acquainted with the audience. When he was at the beginning of college and was asked to speak, he felt uncomfortable because he did not know his colleagues much. He was scared of his friends ' reaction. In his mind, he thought that he must speak well so that other friends would not underestimate him, but indirectly that reason made him fearful.

"In my view, public speaking class enables us to be better at preparing everything before the presentation or speaking in front of many people. I was usually embarrassed to speak English in front of a lot of people, particularly when I was at the beginning of college. It's really disturbing. Maybe it's because I wasn't used to doing that. But now, I enjoy speaking in front of many people who use English" -Student 11

Aplonia Nelci Ke Lomi

LET: Linguistics, Literature and Language Teaching Journal Vol. 9 No. 22019 
"Indeed, the way we speak is different. I'm more scared if there are too many people, I'm actually afraid of being watched by many people, by the way"Student 26

One of the students said she despised the listener's misinterpretation of her statements. She was worried that her friends and the lecturer as the audience could not fully understand what she meant in her speech or presentation. It made her afraid to speak in public.

"I'm afraid the audiences don't know what I'm talking about. I enjoy writing more than talking in front of many people. I'm more afraid they don't understand my explanation. I'm worried that the message could reach them or not. It's like they listen to me, but they don't understand anything" Student 23

"Yes, I realize that my friends have better grammar proficiency than I have. I anticipated the statement from them, for example, "your grammar is bad". I've always asked them how about my grammar? Is that correct? I made a lot of grammar mistakes, didn't I?" -Student 08

Some of the students, however, also indicated that their friends helped them develop their speaking skills. One of the students said his classmates really supported him and sometimes helped him to fix his errors.

"So far, they (friends) really support and listen to me. And sometimes if I was wrong, my friends would remind me and fix my grammar"- Student 10

\section{Lack of Preparation}

For delivering a good public speaking, every speaker should prepare everything well. Some students agree about that. Lack of preparation before presenting speaking in front of many people will probably create anxiety and nervous.

"If there is no adequate preparation for the presentation, I generally get nervous" -Student 11.

Aplonia Nelci Ke Lomi 
A student also said that he had ever faced this kind of situation when he was not sure about the time of the presentation, it influenced badly his performance at the time;

"Because on the day I did not realize it was my turn. I thought it would be in the next week. Surprisingly, it turned out to be mine. I wonder if I had prepared the stuff better. I believe I could do better. The problem was that I wasn't told that far from the day."-Student 11

Lack of references and vocabularies

Some of the students argue that they are lacking in terms of references and vocabulary. And it affects greatly in the way they performing public speaking in the class. One of the examples is student 07 who stated

"Considering my strategies; how do I deal with it, I decided to improve my knowledge, my point of views and my vocabulary. I read Indonesian / English reading texts so that there would be no lack of vocabulary, so what later will I say ... and I also found references styles to speak ... what I read were news, articles and sometimes the videos like TED talk"'-Student 07

Fear of making mistakes and being spotted

Some students claim that they will try hard to prevent making errors when they are speaking in front of their classmates. One of the learners said that the major reason is that she is afraid to face the reactions of her classmates. She is worried that she will cause others to laugh. She also concerns that she might embarrass her mates in the group presentation.

"I'm afraid to make blunders. If I forget what to say in the middle of a presentation and end the speech poorly, it will become much worse. If my speech is not based on what I expect ... I'm scared of embarrassing my group mates. "-Student 09

One of the students also said she was actually afraid of being spotted by others. She does not like being other people's main attention. It makes her feel uncomfortable.

Aplonia Nelci Ke Lomi

LET: Linguistics, Literature and Language Teaching Journal Vol. 9 No. 22019 
"I am afraid of being spotted. I really feel scared when others notice and look at me."- Student 08

Unexpected and unpredictable task/ examination

Based on the students ' previous experiences; they have got sudden tasks and exams several times, and those must be finished in a limited period of time. This definitely made them feel nervous and even unpleasant because they imagined what they had to do in that short time or whether they could finish it well or not.

"That was when we had a presentation in front of other classmates during the 4th semester. There were slides, up to 20 slides. We had to speak according to the slide shown. One slide was ten seconds. And there were only pictures inside, there was no writing at all. We had to explain all the pictures and we didn't fully understand what kind of pictures were. We should do practices, otherwise, it wouldn't succeed. And it really made me nervous because if we miss one slide, it would have an effect on the next slides and could leave us blank." - Student 26

"I've ever played a hot seat game in semester 2, it's the second time I've played that game. The topic is chosen randomly, and you have to speak straight away when you get the topic. There were topics we never noticed and we had to say them in about 3 minutes and the preparation was just one minute. So I said thoughtfully if the topic wasn't familiar with me, I usually talked about what I have heard from my friends.." -Student 23

Another significant point from the result of the questionnaire is $84 \%$ of the students claimed that they are the type of students who will keep trying until they achieve their learning goals especially in acquiring English Public Speaking skill. It is definitely linked to Haggard et al (2013) statement that volition is to the ability to control our actions or behaviors (p. 286). It is also because they realized that other people around them or the environment might not always support them favorably, so they required the will to remain focused on their learning goals. The majority of students displayed a good development of volition in learning public

Aplonia Nelci Ke Lomi

LET: Linguistics, Literature and Language Teaching Journal Vol. 9 No. 22019 
speaking skill. They were determined to face the public speaking or presentation in the midst of various personal distraction and problems.

In facing a presentation in the class, The researcher concluded that all of the students implicitly followed the phases of self-regulation three-stage model purposed by Zimmerman (2000). Before the performance, the students set a learning goal and the volitional strategies (forethought phase). It reflected by their strategies such as making notes and looking for references. They also tried hard to memorize the major points and seeking for help from their colleagues. Then, during the presentation, the students performed the volitional/ performance control strategies. They really attempted themselves to control their emotions such by holding items or hands movements. Those strategies diverted their emotions from the intense pressures of the audiences. They reduced their strong anxiety by being talk active. They also tried hard in controlling their concentration such as by avoiding direct eyes contact with the audiences as they stated that if they look straight into the audience's eyes, their concentration would be interrupted and their focus on the content would be lost. After being engaging in the presentation, they reflected all the mistakes and lacks they experienced. That is the source of all factors come out in this study. The students recognized all the factors above and made better plannings for further presentation.

Furthermore, some students performed examples of unconscious volition in this study, as also supported by Gligorov (2017). The students showed the unconscious volition in hands and body movements strategy. Mostly the students who carry the strategy stated that they were not aware of the strategy before. They did not consciously aware of every single move when performing public speaking. The movements just came up naturally and unconsciously. However, the movements indirectly make them be more comfortable in speaking and handling the anxiety and pressures from and the audiences. Overall, it is indicated that the students in public speaking class used volitional strategies consciously or unconsciously in order to enhance their self-esteem and reduce the level of nervous in performing public speaking. The students also invariably looking for social evaluation. They did evaluation and reflections regarding their past 
experiences and tried best to get better and overcome their anxiety in public speaking.

The findings of this result are not without limitation. The participants in this research are actually divided into two different classes. The 14 students are in class A and 16 students are in class B. The classes also have different lecturers. Thus, there could be different teaching methodologies and strategies presented by two lecturers and it probably affects the students' learning. Then, the researcher conducted face to face interview with five students in class A, whereas the other five students in class B had an online interview. The main reason was the lack of agreement about the meeting with the participants and also the limited duration of the research. Therefore, it could be an issue of validation because the researcher did not meet the five participants directly. So, future researchers are suggested to conduct research with more proper ways and strategies.

\section{CONCLUSIONS AND SUGGESTIONS}

Students in public speaking class, English Language Education Study Program (ELESP) Sanata Dharma University expressed various kinds of opinions and feelings related to the way they acquire the public speaking skill. Based on the analyses and discussions in the previous section, it can be concluded that the students showed a high volitional state in acquiring the public speaking skill. They have several strategies used for achieving their learning goals in the public speaking class. Based on the finding in this research, the majority of the students experience anxiety in speaking. However, they also have strong willpower to overcome the anxiety and distraction that occur and keep trying to do their best in performing public speaking in the class. Therefore, it is a must for the teachers/lecturers especially in public speaking class to be aware of that kind of issue in EFL learning. Paying attention to the role of motivation and volition is helpful for the students in the process of learning the target language. The teacher's awareness of students' volitional strategies and the factors that influenced the students in acquiring public speaking will make the students will be more comfortable to speak in the class. Further researches are necessarily needed with the different context of learning or methodologies. 


\section{REFERENCES}

Bartels, J., Magun-Jackson, S., \& Kemp, A. (2009). Volitional regulation and selfregulated learning: An examination of individual differences in approachavoidance achievement motivation. Electronic journal of research in educational psychology, 7 (2), 605-626.

Blöte, A. W., Kint, M. J., Miers, A. C., \& Westenberg, P. M. (2009). The relation between public speaking anxiety and social anxiety: a review. Journal of anxiety disorders, 23(3), 305-313.

Corno, L. (1993). The best laid plans: Modern conceptions of volition and educational research. Educational Researcher, 22(2), 14-22

Corno, L., \& Kanfer, R. (1993). The role of volition in learning and performance. In L. Darling- Hammond (Ed.), Review of Research in Education (Vol. 21, pp. 301-341). Itasca, IL: F.E. Peacock Publishers.

Creswell, J. W. (2014). A concise introduction to mixed methods research. Sage Publications.

Deci, E. L., Vallerand, R. J., Pelletier, L. G., \& Ryan, R. M. (1991). Motivation and education: The self-determination perspective. Educational Psychologist, 26(3-4), 325-346.

Deimann, M., \& Bastiaens, T. (2010). The role of volition in distance education: An exploration of its capacities. The International Review Of Research In Open And Distributed Learning, 11(1), 1. doi: 10.19173/irrodl.v11i1.778

Dincer, A., \& Yesilyurt, S. (2017). Motivation to Speak English: A SelfDetermination Theory Perspective. PASAA Journal Of Language Teaching And Learning, 53, 1-25. Retrieved from https://files.eric.ed.gov/fulltext/EJ1153672.pdf

Elstad E. (2012) Volition for Learning. In: Seel N.M. (eds) Encyclopedia of the Sciences of Learning. Springer, Boston, MA

Feldon, D. F., Podolskiy, D., Elliott, J., Merriënboer, J. J. G., Orgill, M., Palmer, D. C., Matthews, R. S. (2012). Volition for learning. Encyclopedia of the sciences of learning, 3427-3429. doi:10.1007/978-1-4419-1428-6_101

Gaeta, M. L., Teruel, M. P., \& Orejudo, S. (2012). Motivational, volitional and metacognitive aspects of self-regulated learning. Electronic Journal of Research in Educational Psychology, 10(1), 73-94. Retrieved December 10, 2018, from http://investigacionpsicopedagogica.com/revista/articulos/26/english/Art_26_640.pdf

Aplonia Nelci Ke Lomi

LET: Linguistics, Literature and Language Teaching Journal Vol. 9 No. 22019 
Gagné, M., Koestner, R., \& Hope, N. (2014). A Self-Determination Theory Approach to Goals. The Oxford Handbook of Work Engagement, Motivation, and Self-Determination Theory. doi:10.1093/oxfordhb/9780199794911.013.025

Gligorov, N. (2017). Unconscious Volition. AJOB Neuroscience, 8(3), 151-152. doi: $10.1080 / 21507740.2017 .1366583$

Haggard, P., \& Lau, H. (2013). What is Volition? Experiment Brain Research, 229(3), 285-287. doi:10.1007/s00221-013-3582-5

Jamshed, S. (2014). Qualitative research method-interviewing and observation. Journal of Basic and Clinical Pharmacy, 5(4), 87-88. http://doi.org/10.4103/0976-0105.141942

Keller, J. M., Deimann, M., \& Liu, Z. (2005). Effects of integrated motivational and volitional tactics on study habits, attitudes, and performance. 2005 Annual Proceedings-Orlando: Volume, 234.

Kuhl, J. (1985). Volitional mediators of cognitive-behavior consistency: Selfregulatory processes and action versus state orientation. In J. Kuhl \& J. Beckmann (Eds.), Action control: From cognition to behavior (pp. 89100). Berlin: Springer Verlag

Lee, B. S. (2017). The Fundamentals Of Q Methodology. Journal of Research Methodology, 2(2), 57-95. doi:10.21487/jrm.2017.11.2.2.57

Mbato, C. L. (2013). Facilitating EFL learners' self-regulation in reading: Implementing a metacognitive approach in an Indonesian higher education context (Master's thesis, Southern Cross University, 2013) (pp. 1-241). Lismore: EPublications@SCU. Retrieved October 10, 2018, from https://epubs.scu.edu.au/theses/353/

Mccann, E., \& Turner, J. (2004). Increasing Student Learning Through Volitional Control. Teachers College Record, 106(9), 1695-1714. doi: 10.1111/j.1467-9620.2004.00401.x

Macintyre, P. (2007). Willingness to Communicate in the Second Language: Understanding the Decision to Speak as a Volitional Process. The Modern Language Journal, 91(4), 564-576. doi: 10.1111/j.15404781.2007.00623.x

Nikitina, A. (2011). Successful public speaking. Bookboon.

Onoda, S. (2014). Examining the relationships between self-efficacy, effort regulation strategy use, and English vocabulary skills. Studies in a selfaccess learning journal, 5(4), 357-371

Aplonia Nelci Ke Lomi

LET: Linguistics, Literature and Language Teaching Journal Vol. 9 No. 22019 
Participant Consent Form [Web log post]. (n.d.). Retrieved October 12, 2018, from https://www.tcd.ie/swsp/assets/pdf/Participant consent form template.pdf.

Ryan, R. M., \& Deci, E. L. (2000). Self-determination theory and the facilitation of intrinsic motivation, social development, and well-being. American Psychologist, 55(1), 68.

Sari. P.(2012). Improving Students' Speaking Achievement Through Public Speaking Tasks. TRANSFORM Journal of English Language Teaching and Learning of FBS UNIMED, 1(1), 1-8. Retrieved December 15, 2018, from https://jurnal.unimed.ac.id/2012/index.php/jelt/article/view/367.

Shatrova, Z. (2016). Facilitating English Learners' Speaking: Toastmasters Meeting as a Format for the ESL Speaking Class. International Journal of English Language Education, 4(1), 106. doi:10.5296/ijele.v4i1.8861

Volition | Definition of volition in English by Oxford Dictionaries. (n.d.). Retrieved from https://en.oxforddictionaries.com/definition/volition

Volitional Learning Strategies. (n.d.). SpringerReference. doi:10.1007/springerreference_301772

Wang, W. (2011). The Impact of Volitional Feedback on Learners' Self-Efficacy and Course Satisfaction in a College Assignment System (Doctoral dissertation, Virginia Polytechnic Institute, and State University, 2011) (pp. 1-112). Virginia: VTechWorks. http://hdl.handle.net/10919/29149

Wisdom, J., \& Creswell, J. W. (2013). Mixed methods: integrating quantitative and qualitative data collection and analysis while studying patient-centered medical home models. Rockville: Agency for Health care Research and Quality.

Yee, K. M., \& Abidin, M. J. (2014). The Use of Public Speaking in Motivating ESL Learners to Overcome Speech Anxiety. International Journal on Studies in English Language and Literature (IJSELL), 2(11), 127-135. Retrieved November 20, 2018, from https://www.arcjournals.org/pdfs/ijsell/v2-i11/16.pdf.

Zimmerman, B. J. (2000). Handbook of Self-Regulation. Eds: Boekaerts, M., Pintrich, P., R., \& Zeidner, M. E-book, Elsevier INC, 2000.

Aplonia Nelci Ke Lomi

LET: Linguistics, Literature and Language Teaching Journal Vol. 9 No. 22019 